\title{
LOW-COST HOUSING PROVISION IN NIGERIA: LESSONS FROM THE MALAYSIA EXPERIENCE
}

\author{
Andrew Ebekozien*, Abdul-Rashid Abdul-Aziz, and Mastura Jaafar \\ School of Housing, Building and Planning, Universiti Sains Malaysia, Pulau Pinang, Malaysia \\ E-mail: *ebekoandy45@yahoo.com
}

\begin{abstract}
This article discusses the housing policy of two developing economies. It examines recent research findings in the light of encumbrances facing the Nigerian housing policy with an emphasis on low-cost housing (LCH) development. It also evaluates how the Malaysian Government over the years have made a good attempt to make homeownership affordable for Malaysian citizens irrespective of their income with various LCH policies and programmes that are economically feasible and technically practicable. It examines studies in the Nigerian housing sector that revealed severe scarcity, high cost of $\mathrm{LCH}$, inaccessibility to housing loan, weak LCH policy, high corruption, high inflation among others. This affords insights into the Malaysian potential policy practices that could be implemented in Nigeria to address the prolonged chronic housing problem. Hence, it evaluates whether the Malaysian LCH policy can be modified and applied in the Nigerian context as possible policy measures. The article shows that the Malaysian Government sees housing provision as one of the major pillars and synergy with other constructs of welfare in line with the system embedded approach. Furthermore, this approach appears to be gaining ground and would stir-up the Nigerian Government policy-makers with poor-friendly policies so that LIEs can gain access to homes.
\end{abstract}

Keywords : Developing Economies, Low-Cost Housing, Low-Income Earners, Malaysia, Nigeria

\section{INTRODUCTION}

Housing the masses is an important agenda for nations over the world, thus, the right to housing as a basic need cannot be overemphasised. A residential home is the second indispensable need for every human being after food (Maslow, 1943; United Nations Habitat 11, 1996; Ebekozien, Abdul-Aziz, \& Jaafar, 2017; Ebekozien 2019). The latter authors opined that the arrangement of sufficient low-cost housing (LCH) in any nation is extremely fundamental as housing is a stimulant of the national economy. Housing is an arrangement of powerful resources, which represents a high extent of a nation's riches and on which family units spend a significant piece of their monthly income (Ebekozien et al., 2019A). This is in line with Kemeny (2001) assertion. The scholar opined that among the four major pillars of the welfare state (social security, health, education, and housing), housing is being characterised by high capital intensity and the special roles it plays in terms of synergy with other dimensions of welfare. Hence, this has stirred-up the need for the researchers to evaluate housing provision from the perspective of welfare provision. Whilst Ibem (2012) asserted that LCH delivery is a contentious and politicised issue, especially in developing countries. Past Nigerian politicians over the years have come with various promises regarding housing provision but in the end, it turns to fallacy. The scarcity of housing affects all segments of society. Records have shown that in Nigeria, the low-income earners (LIEs) are the most affected (Ebekozien et al., 2017; 2019A). This is because the Nigerian LIEs are excluded from formal housing provision by the government and urban housing developers. The few LCH units constructed by the government end-up in the hands of medium and medium-high income earners because of the weak LCH policy and institutional framework to identify eligibility.

The problem of LCH provision is an increasing social and economic issue in the world, most hit in the developing countries (Ebekozien et al., 2019B). One of the possible reasons is the isolation of housing research by scholars. The need for housing to take the centre place of welfare research should be encouraged and this would generate explained theoretical basis that is capable of being subjected to empirical testing (Kemeny, 2001). This is 
one of the reasons this article is addressing LCH issues and offered a comparative analysis that affords insights into the Malaysian potential policy practices that could be implemented in Nigeria in line with Bengtsson and Ruonavaara (2011) and Alves (2017) studies. The previous scholars adopted comparative process tracing as an analysis in their study. The latter author opined that remarkable differences in housing policies can be observed across countries. Denis (2011) reported that 22.3 million (21.1\%) of the American households had the challenge of housing affordability in the year 2000. This can be clarified as the gap between the low-income group and the base expense of reasonable accommodation. This situation is not dissimilar in Nigeria. The 20th century saw several failed attempts by the Nigerian Government and the ruling class to provide LCH for the LIEs (Aribigbola \& Ayeniyo, 2012). While scholars like Okoroafor (2007); Wapwera, Parsa, and Egbu (2011) explained that the Nigerian LCH problem is both in quality and in quantity, and coupled with non-availability of finance for the LIEs. Even when it is available, conditions attached to its accessibility is unaffordable, therefore makes the LIEs ineligible for the housing loan (Ilesanmi, 2010). The natural population increase, migration from rural to urban cities for better opportunities and inadequate responses by the government at various levels has contributed to the worsening LCH situation in Nigerian cities. Wahab (2006, p.5) defined a LIE as "an employee or person in the informal sector that is self-employed whose monthly income is within NGN18,000 to N40,000" (1US\$/NGN360 as at 21 st November 2018). The minimum income by law is NGN18,000/month but there is an indication of a possible increase to NGN30,000 from the year 2019.

United Nations Habitat Agenda Paragraph 53 affirmed that over one billion are living in an undesirable condition of shortage and lack sufficient homes (United Nations Habitat II, 1996). World Bank Press Release (2017) opined that enhanced home provision has additionally been demonstrated to positively affect general wellbeing, training and work constrain results. This indicates that housing is one of the major variables that influence human health. This is in line with Kemeny (2001). The author claimed that two contrasting underlying philosophies have developed in the state's role in the provision of housing, whichever approaches that is adopted, it always a "win-win approach" to the LIEs in these welfare states. In the opinion of Fahey and Norris (2011), housing provision should be seen as a service, thus demands a variety of continuing state intervention. Aribigbola (2012) asserted the need for innovative and productive delivery of LCH to low-income groups because of its relevance to human existence. While scholars like Awodele (2012) argued the need for more comparative regional studies of LCH provision in Nigeria and such comparative studies will enhance the understanding of the encumbrances facing LCH provision in Nigeria. This is one of the existing gaps this article would attempt to fill as part of the contribution to the body of knowledge. This paper reviewed the Nigerian and Malaysian LCH provision respectively and offered a comparative analysis that affords insights into the Malaysian potential policy practices that could be implemented in Nigeria to address the long-time chronic housing problem. The Malaysian Government has recorded some success in the provision of $\mathrm{LCH}$ among the developing countries in the world (Shuid, 2016). The homeownership concept of one democracy, one household via various Malaysian housing regulatory policies is a good example of the pro-poor policy for the LIEs. This is where the Public Interest Theory of Regulation operates and the government willing to make homeownership a reality for all Malaysian household irrespective of the household income (Ebekozien, 2019). The two countries have many similarities, political and economy-wise. For example, both countries were colonised by British Government, secured independence almost the same period, Malaysia (1957) and Nigeria (1960) respectively, and both run the federal system of government, both have crude oil among others. The next section presents the methods to collect and analyse the literature used in this paper.

\section{METHODS FOR COLLECTING AND ANALYSING LITERATURE}

Many approaches were adopted to collect and analyse the literature used in this article. First, searches were conducted from the database until June 2019. Our literature search used the following keywords: "low-cost housing in Malaysia", "low-cost housing in Nigeria", "housing for the poor in Nigeria", and "Malaysia's experience in housing provision." The most helpful article was Ebekozien et al. (2017) that contained a comparative study of LCH in Malaysia and Nigeria as reviewed. This article explored literature from different background, searched for primary studies in Malaysian Citation Index, Web of Science, ScienceDirect, Scopus, and Google Scholars. Only the database searches in ScienceDirect was limited. It is necessary to state here that one of the reasons for the exploration of the Malaysian Citation Index was because of the peculiarity of the keywords regarding Malaysia to have a better experience. At the end of the search, 75 articles were identified. From the 75 articles found, only 45 were deemed to be relevant to this article, were retrieved and reviewed. The next section presents a discussion of the reviewed literature. 


\section{DISCUSSION}

This section is divided into two: low-cost housing provision in Nigeria and the second part is low-cost housing: The Malaysia experience.

\subsection{Low-Cost Housing Provision in Nigeria}

This section gives a brief history of LCH in Nigeria. LCH in most Nigerian communities and cities before the British rule was provided through a communal system. Family in a group, peer groups, associations would turn out en masse on a pre-arranged day to assist in the building process in whatever task of the housing project. In return, the house owner would provide food while the project lasted and give in return the favour to others when they are ready to build too. Government intervention in housing began during the British period (1928-1960). The written history of formal mediation into the Nigerian housing industry dated back to the British rule period, after the disastrous upheaval of the bubonic plaque of 1928 in Lagos (Ibimilua \& Ibitoye, 2015). This gave birth to the establishment of the Lagos Executive Development Board in 1955 (Ilesanmi, 2010). This showed the introduction of Nigerian public housing programmes intervention (Aribigbola, 2008). The significant of the colonial period was the development of staff quarters for international and other Nigerian staff of parastatals and organisations in government. This period saw the establishment of Urban Councils in 1946, the Nigerian Building Society in 1955 and the Regional Housing Corporation in 1959 in that order. The post-colonial era encountered some advancement in LCH provision amid the First National Development Plan period (1962-1968) and the Second National Development Plan 1970-1974) in that order. To address the housing needs of the masses, the initiation of the National LCH Scheme was done in 1975. Less than $15 \%$ of the 202,000 LCH units were developed within the Third National Development Plan (1975-1980) at about US\$2.6 billion (Ibem, 2012). The LCH Scheme failed because of the alleged high corruption and birthed the Site-and-Service's Programme that failed too. Ajanlekoko (2001) asserted that between 1986 and 1991, about US\$21.25million was used in providing 20,000 serviced plots in 20 states for the middle and high-income earners because the LIEs could not meet the requirement for allocation.

Some scholars like Ibem, Anosike, and Azuh (2011) and Okonkwo, Agbonome, and Chiroma (2012) opined that between 1975 and 2010, numerous LCH programmes involving development by the Federal Military and Civilian Governments in Nigeria commenced. They include the National LCH Scheme (1975-1980), Shagari's LCH Programme (1980-1985), the National Housing Programme (1994-1995), the National Prototype Housing Programme (2000-2003), and the Presidential Housing Mandate Scheme (2004-2006) as presented in Table 1. Table 1 shows the proposed number of housing units from 1962 to 2010 was 653,271 units; only 95,594 units were completed, that is about $14.63 \%$. This is low, thus, the need to declare a state of emergency for housing provision (Ebekozien et al., 2019A). Also, Table 1 indicates that none of the previous programmes achieved up to $50 \%$ of the projected housing units, apart from the period between 2006 and 2010 (43\% achievement). UNHABITAT (2010) opined that $61.9 \%$ of the urban population in Nigeria as of 2010 lives in slums. This is worrisome. This shows that the previous alleged $\mathrm{LCH}$ programmes and policies did not have a significant impact on LCH provision. Based on this figure, in the opinion of some scholars like Ibem, Opoko, and Aduwo (2013), the previous housing programmes were insignificant to bring positive impact to the housing sector. This confirms Aigbokhan (2008) submission that Nigerian Government housing policies seem to be encouraging high inequality and disparities in access to financial credit, tailored to favour the medium and high-income earners only. To achieve homeownership for the LIEs, housing policy and research agendas should be more transparently based upon a thoughtful of the developmental dialectic, regarding political, social and economic matters (Pugh, 2001; Ebekozien et al., 2019A). Whilst Keivani and Werna (2001a, 2001b) opined that housing developers even though supported, that cannot form the focus of enabling environment in most developing countries. This indicates that the government should be a participatory factor in housing provision for the poor and disadvantaged in developing countries such as Nigeria.

Odunsi (2017) averred that in August 2017, Central Bank of Nigeria rolled out a programme called "My Own Home". It is hoped that this programme succeeds since it is backed by the World Bank, Federal Ministry of Finance, Federal Ministry of Power, Works and Housing, Federal Ministry of Justice, Mortgage Banking Association of Nigeria, and Primary Mortgage Banks. The saddening aspect of this programme is that about $95 \%$ of the low-income group may not benefit from the scheme because of the inability to fulfil the conditions to participate such as $10 \%$ down payment minimum, collateral, guarantor, and evidence of regular income as presented in Table 2 in one of the states (Edo State). This cut across the country. This is a policy that tends to 
favour the medium and high-income earners than the low-income group. The government needs to revisit this policy the purpose is defeated. Also, in a few states that developed homes, the high price automatically disqualifies the LIEs; while bureaucracy, favouritism, and politics involved are very high. These are some of the issues that hampered the LIEs in a system where there is no enforcement of regulation to protect the less privileged. Aliu, Towry-Coker, and Odumosu (2018) found that cost affordability, policy objective implementation, mortgage finance, and government community conflicts were identified as the basis of the public housing programme failure in Lagos. These factors cut across the country.

Table 1: Low-Cost Housing Schemes by the Federal Government of Nigeria (1962- 2010)

\begin{tabular}{llll}
\hline Period & Proposed number of housing units & Number housing units produced & Percentage Achieved \\
\hline $1962-1968$ & 61,000 & 500 & 0.81 \\
$1971-1974$ & 59,000 & 7,080 & 12.00 \\
$1975-1980$ & 202,000 & 30,000 & 14.85 \\
$1981-1985$ & 180,000 & 47,234 & 26.24 \\
$1986-1999$ & 121,000 & 5,500 & 4.55 \\
$2000-2003$ & 20,000 & - & - \\
$2004-2006$ & 18,000 & 840 & 4.67 \\
$2007-2010$ & 10,271 & 4,440 & 43.23 \\
TOTAL & $\mathbf{6 5 3 , 2 7 1}$ & $\mathbf{9 5 , 5 9 4}$ & $\mathbf{1 4 . 6 3}$
\end{tabular}

Source: Modified from Onibokun (1985), UN-HABITAT (2006), Ibem et al. (2011), Ebekozien et al. (2017).

Table 2: Price List of the Joint Venture between Edo Development and Property Agency

\begin{tabular}{|c|c|c|c|c|c|}
\hline \multicolumn{6}{|c|}{ Payment Plan Shell Finish } \\
\hline & & & Brass & Coral & Bronze \\
\hline & & & $\begin{array}{l}2 \text { Bed-Cluster } \\
\text { Bungalow }\end{array}$ & $\begin{array}{l}3 \text { Bed-Twin } \\
\text { Bungalow }\end{array}$ & $\begin{array}{l}3 \text { Bed-Cluster } \\
\text { Bungalow }\end{array}$ \\
\hline \multicolumn{3}{|l|}{ Finish } & Move-in-Ready & Move-in-Ready & Shell \\
\hline \multicolumn{3}{|l|}{ Price } & NGN5,000,000 & NGN8,000,000 & NGN15,000,000 \\
\hline \multicolumn{3}{|c|}{ Total Payable (Incl. fees) } & NGN5,750,000 & NGN9,200,000 & NGN17,825,000 \\
\hline \multicolumn{3}{|c|}{ Payment Period } & 18 Months & 18 Months & 18 Months \\
\hline $1^{\text {st }}$ Payment & $25 \%$ & Upon Sales & NGN1,437,500 & NGN2,300,000 & NGN4,312,500 \\
\hline $2^{\text {nd }}$ Payment & $20 \%$ & Month 3 & NGN1,150,000 & NGN1,840,000 & NGN3,565,000 \\
\hline $3^{\text {rd }}$ Payment & $20 \%$ & Month 6 & NGN1,150,000 & NGN1,840,000 & NGN3,450,000 \\
\hline $4^{\text {th }}$ Payment & $15 \%$ & Month 9 & NGN862,500 & NGN1,380,000 & NGN2,587,500 \\
\hline $5^{\text {th }}$ Payment & $10 \%$ & Month 12 & NGN575,000 & NGN920,000 & NGN1,725,000 \\
\hline $6^{\text {th }}$ Payment & $10 \%$ & Upon Completion & NGN575,000 & NGN920,000 & NGN1,725,000 \\
\hline \multicolumn{3}{|c|}{ Service Charge Deposit 2 year Service Charge } & NGN200,000 & NGN200,000 & NGN200,000 \\
\hline \multicolumn{3}{|l|}{ Survey Fees } & NGN100,000 & NGN100,000 & NGN100,000 \\
\hline
\end{tabular}

Source: Modified from Joint Venture Partnership between Edo Development and Property Agency (Mixta Real Estate Plc.).

In 2012, the National Housing Policy that promised Nigerians real mass housing which the country has been dreaming of was commissioned (Abdullahi, 2013). A country with a population of over 192 million are hoping that this would manifest one day but with no evidence of institutional framework that could act as a panacea for the provision of LCH (Ebekozien et al, 2017). Lack of LCH institutional and regulatory policy framework is the major contributors to this protracted problem (Abdullahi, 2013, Ebekozien et al, 2017; 2019A). Akintomide (2016) affirmed that an estimated 24.4 million Nigerians are homeless as released by the United Nations. One fact not disputable is the severe shortage of housing for the LIEs in Nigerian urban cities with increasing "urban squatters" daily. Lack of access to housing loan, unavailability of land and basic infrastructures, fraud in the performance of different past LCH policies, quick urbanisation without planning, high disparities in income, shortage of LCH supply, and terror acts among others led Nigeria to this deplorable present condition (Ebekozien et al., 2019A). For example, the Boko-Haram Terrorists' Organisation has exiled over 650,000 Nigerians internally and 70,000 as refugees in adjoining countries (The Guardian, 2017). Houses being destroyed even with the existing shortage, creating a more man-made shortage. 
Amaefule (2017, p6) reported that the Nigerian Federal Government at the 2017 Housing Summit in Abuja,

As at 1991 when the National Housing Policy was promulgated, Nigeria was said to have a housing deficit of 7 million units. For close to three decades now, the figure has been put at 17 million, thus putting to question the reliability of these statistics (p. 6).

The government needs to set-up a technical committee to verify this figure and enhance proper planning in the future. However, the Bureau of Public Service Reform (2017) claimed that about 108 million Nigerians are on the streets. Bureau of Public Service Reform is a self-governing and self-accounting organisation with a directive to initiate, organise and make certain full execution of the government reform policies and programmes. While the Chairman, National Population Commission put the population at about 198 million with urban population growing at an average annual growth rate of about $6.5 \%$ (Adeyemo, 2018). The Nigerian Governments (federal and state levels) need to declare a state of emergency on LCH and lead in the LCH provision. Countries all over the world that have succeeded in housing provision for her citizens, for example, Singapore, Hong Kong, Austria among others lead in the provision of housing and soft housing loans to purchase a home or rental rate subsidised for the LIEs (Phang, 2018). This is what the Public Interest Theory of Regulation is all about; implementation of policies and programmes that represent the public interest best allocations of insufficient resources for the masses common satisfaction (Pigou, 1932; Ebekozien, 2019).

In Nigeria, few states that are involved in housing provision concentrate on medium and medium-high income housing provision (Wapwera et al., 2011). One of the major reasons is because the LIEs would not be able to access housing loan or the selling price is on the high side because there is no selling price regulation (Ebekozien et al., 2017). This submission corroborated the former Lagos State Commissioner for Lands, urging governments to consider disparities in income while making housing policies so that the LIEs could be accommodated in their policy framework. Olufowobi (2017) reported that the former commissioner was a guest in the 2017 World Habitat Day said:

Lagos State Government, one of the scanty states that have made a remarkable impact in housing provision, has been able to deliver a total of 4,355 housing units across the three senatorial districts of the state under the rent-to-own scheme (p. 1).

This is a good development but not accessible to the LIEs category in the state. Hence, reviewing the Nigerian LCH policies and institutional framework of ministries, department, and agencies in charge of housing provision; to make the policies LIEs homeownership friendly cannot be over-emphasised.

At a housing finance event, the Nigerian Government said they were working with stakeholders to raise NGN1.0 trillion to provide affordable housing for Nigerians (Punch Newspaper, 2016). The federal government intended to have a programme called the Family Home Fund via Sovereign Wealth Fund, Federal Government Bonds and Bank of New York through public and private partnership. The Guardian (2017) reported that in March 2017, the federal government announced it would waive an initial 10\% payment on a mortgage below NGN5 million given by the state-owned Federal Mortgage Bank of Nigeria to target future homeowners taking out mortgages. The LIEs are hoping that this programme would commence one day as hope seems to decline. This is the differences between the Malaysian and Nigerian Governments. The Malaysian Government is devoted to her citizenry housing welfare in words, policies, and action. LIEs in Malaysia can access fund from mortgage to purchase $\mathrm{LCH}$ at regulated government price, sometimes subsidies by the government via cross-subsidisation or direct subsidisation for her citizens to gain access to the home, although there is room for Malaysia's homeownership improvement (Ebekozien et al., 2018; Ebekozien, 2019).

In February 2015, the Central Bank of Nigeria successfully licensed the Nigeria Mortgage Refinance Company Plc with the core function of the refinancing of mortgages of its member banks in 2015 (Mortgage Digest, 2016A). As at the end of the 3rd quarter of 2016, NGN 7.8 billion worth of mortgage has been refinanced (Mortgage Digest, 2016B). The Mortgage Refinance Company seems to have made a positive impact on affordable housing such as Federal Integrated Staff Housing (FISH) Programme; and managed by the Head of the Civil Service of the Federation. While the Mortgage Market Management System, deploy transformative Housing and Mortgage Market Information Portal are tailored to medium and medium-high income earners. The same is applied to the Federal Housing Authority. The FISH Programme is a private sector-driven without regulation on ceiling prices. The Federal Housing Authority was established vide Decree 40 of 1973 that ought to address the housing need of all, inclusive of the LIEs in the public sector but became possibly commercialised by Decree 
No.25 of 1988. The Federal Housing Authority is under the National Housing Programme that came up with some transition strategies from the public to the privately developed housing via private developers. Allowing a welfare scheme such as housing to be partially commercialised and left only to profit-driven private enterprises means that the LIEs are cut off from such a scheme. This is the Nigerian housing sector scenario. Other reasons are nonthoughtfulness of LIEs by housing developers in their design, lack of access to the credit facility, low incentives and concessions to investors, high cost of land in urban cities, absence of primary infrastructure, high cost of building inputs, and slow bureaucratic procedures (Oyo-Ita, 2017). The federal government attempted to address the housing loan aspect by the introduction of the Social Housing Fund. For a person to be eligible to access this social fund, the person should be able to make a repayment of NGN30,000 per month. How many Nigerian LIEs can afford NGN30,000 (US\$83.3) per month as a contribution to the scheme?

The Federal Housing Authority acknowledged the cumbersome process in accessing fund from the National Housing Fund that ought to be for civil servants in the country. The management is planning collaboration with the cooperation of other government agencies to build civil servants houses within the bracket of NGN5 million to NGN15 million and follow-up to get the money from the federal mortgage (Alao, 2017). This programme is the same as the previous ones, majorly for medium and medium-high income earners. The released Central Bank of Nigeria policy on mortgage lending rates stated that lending at monetary policy rate (MPR) $+5 \%$ for commercial mortgages, and did not stipulate a rate for construction financing and as such, become relaxed to monitor and enforce the mortgage banks to decide whether to fund mortgages at a capped rate or fund construction at a more lucrative rate (Mortgage Digest, 2017). This is a disadvantage to the LIEs but an advantage to the mortgage institutions.

The high demand for LCH and non-availability of finance hindered the non-profit organisations progress in tackling the housing deficit challenge in Nigeria (Raschke, 2016). The construction of LCH by the non-profit organisation is possibly one of the panaceas to solving the Nigerian housing dilemma. For example, Millard Fuller Foundation, a non-profit house-builder, recently embarked on a scheme in Luvu-Madaki, Masaka, Nasarawa State, Nigeria. A studio is sold for NGN1.65 million, one-bed for NGN2.7 million with both options targeted at LIEs. A provision is made for an upgrade from studio to one-bedroom and one-bedroom to two-bedroom as the family grows once payment has been made fully. Another example is the joint initiative between Lafarge and LAPO Microfinance Bank. LAPO provides the clients with micro-loans to pay for the projects at $1.63 \%$ per month within a time frame while Lafarge provides free technical assistance comprises basic architectural plans based on individual needs and bill of quantities, including material schedules where necessary. Over 2,700 families have been reached via this scheme, although, it has become a profit-making avenue for Lafarge with profits generated through the sale of materials (cement and blocks). Sustainability and coverage is the major challenge faced with this mechanism, and statistics show that around 86.9 million Nigerians lived in extreme poverty and have the largest extreme poverty population (Kazeem, 2018).

\subsection{Low-Cost Housing: The Malaysia Experience}

This section gives a brief history of Malaysian LCH and action taken by the Government at different levels regarding the provision of $\mathrm{LCH}$ to her citizens. $\mathrm{LCH}$ is provided by both the government and private housing developers in Malaysia. The Malaysian housing system is more of the "middle-range" as categorised by Kemeny and Lowe (1998). This is one of the dominant perspectives and to discern typologies of housing systems. The middle range is between the privatisation and recommodification of welfare on one hand and comprehensive welfare states on the other hand. The Malaysian housing policies balance the two perspectives with regulations. Shuid (2016) categorised housing provision into four phases namely: Housing the Poor (1971-1985), Market Reform (1986-1997), Slums Clearance (1998-2011), and lastly, State Affordable Housing (2012-to date). Scholars like Stone (2006) and Ebekozien et al. (2017) asserted that during the pre-independence period before 1957, the government was the major provider of housing. In between 1956-1964, the first and second Malaya Plans were rolled out. This period saw more LCH from the public and private sectors. The first Malaysia Plan (1965-1970) had the express acknowledgement of the government's duty of housing the LIEs (Abdul-Aziz, Tah, Olanrewaju, \& Ahmed, 2018). Mohammed, David, and Seow (2012) affirmed that amid the sixth MP (1991-1995), the National Development Plan took-off, and the private industry remained major stakeholder and the government made numerous new laws and rules to guarantee quality housing, for instance, the 1991 National Housing Policy.

In the year 1982, during the 4th MP (1981-1985), the Malaysian housing sector saw the introduction of compulsory construction of LCH by private developers (Abdul-Aziz et al., 2018). Ebekozien et al. (2017) and Ebekozien (2019) asserted that the year 1982 denoted a watershed in Malaysian Government; forced a 30\% LCH 
development to private housing developers to ensure the private sector build LCH in every residential project. In the same MP period, the Malaysian Government introduced privatisation policy to encourage private sector involvement in national development including LCH sub-sector. Note, Malaysian Government did not "barked-out or cold" like what we are experiencing in Nigerian LCH provision, the government is still a strong provider and regulator/facilitator of $\mathrm{LCH}$ provision to date with a mechanism to monitor operations. For the Nigerian Government, the emphasis is only on high and medium-income earners. The need for the Nigerian Government to review her housing policies for the benefit of mankind by adopting the Malaysian LCH model cannot be overstressed.

In the 10th MP (2011-2015) period, the government established the Housing Maintenance Fund to address the concern of poor housing preservation. The Malaysian National Housing Policy was launched on 10th February 2011, that is, during the tenth MP (10th MP, 2010). Eleventh MP (2016) reported that the 11th MP is interesting to the Malaysian Government; it is the last arrangement before the year 2020 focus of turning into an advanced country. The government will keep on assuming a noteworthy job in meeting the housing needs of the LIEs group in urban and rural environs by keeping supporting existing fruitful policies and programmes through financing and development. This includes programmes under Rumah Mesra Rakyat 1Malaysia, Program Perumahan Rakyat, My First Home Scheme, Youth Housing Scheme, MyHome (Abdul-Aziz et al., 2018). For example, over 83,750 units of LCH have been built by the public housing unit, according to the Ministry of Urban Wellbeing, Housing and Local Government. This is only one of the LCH programmes, while for the housing loan, in the year 2018, a total of 1,469 applicants benefited from My First Home Scheme. The government provided a $10 \%$ deposit on the sale price or a maximum of RM30,000 (whichever is lower) (Ebekozien et al., 2018). The applicant is not expected to pay back the $10 \%$ or RM30,000; it is a token contribution from the Malaysian Government to her citizens. Viewpoint from scholars like Fahey and Norris (2011) averred that welfare advantage of homeownership lies in its generally perceived social protection as well as in productivity. Nigeria can get it right if corruption and politics are set aside by those in authorities. In Malaysia, houses are constructed for youth and young family couples in cities, including those proposed under the 1 Malaysia Youth City Programme. These houses are utilised as transit homes for these young family Malaysians, to give them a chance to make reserve funds to purchase their homes. Likewise, the public-private partnership is being urged as a panacea to solving the housing demand-supply gap in Malaysia (Abdul-Aziz \& Kassim, 2011). The concept of the public-private partnership is controlled by the government. Developers are mandated to develop LCH within a certain range of development and the selling price fixed by the government for the $\mathrm{LCH}$. The conditions for the development of LCH vary from state to state; this is not a free for all for the Malaysian housing developers like in Nigeria.

Malaysian Government long ago recognised the importance of building a sustainable housing finance system. Fernande (2013) averred that Bank Negara Malaysia (Central Bank of Malaysia) recognised that the prerequisites of successful homeownership programmes are housing finance availability and accessibility. This is evident by the outstanding amount of LCH loans granted by housing credits institutions based on the strong supervisory functions played by BNM as the main regulator. The Central Bank of Nigeria should adopt the Central Bank of Malaysia approach. This is the kind of masses model that the Nigerian LIEs need, and hoping that the government would summon the political will since it is not affecting the ruling class to do the needful. Ebekozien et al. (2017) affirmed that the Malaysian Government continues to introduce new measures to facilitate the housing finance system by managing property prices and excessive speculation in the market (Ebekozien et al., 2019B). Some of the key measures introduced in the past seven years include:

1. RM1 billion funds for affordable homes of households income not above RM2,300 per month for property up to RM150,000 (The Star Online, 2018).

2. Withdrawal from the Employee Provident Fund to pay monthly instalments for the housing loan. EPF is similar to PenCom in Nigeria.

3. Higher Real Property Gains Tax and higher minimum purchase price for foreign homeownership.

4. The four-unit limit for bulk purchase by individuals.

5. Provision of affordable and quality LCH for all Malaysians in various income levels with the introduction of many affordable housing schemes, inclusive of LCH (also known as affordable housing Type A), examples of these already highlighted in the previous paragraph (Ebekozien et al., 2017).

The Malaysian housing computerised open registration system, although not a perfect one, assisted the Malaysian Government in mitigating leakages in LCH provision. The registration system is a mechanism employed by the Ministry of Urban Wellbeing Housing and Local Government (MUWH\&LG) in the processes and procedures associated with the buying and owning of LCH by eligible Malaysian citizens (MUWH\&LG, 
2013; Abdul-Aziz et al., 2018; Ebekozien et al., 2018). It is also a platform for documenting houses ready for sales from both private developers and government from federal to states, then to districts at a regulated price by the government and in some instances, subsidised by the government for her citizens (Parkers, 2016). This is missing in the Nigerian housing sector because the public and private sectors have failed to construct LCH for the LIEs. This indicates a lacuna in the implementation of the 2012 Nigerian National Housing Policy that has good intentions for the masses. Therefore, a functional computerised open registration system via an integrated database on LCH supply and demand is one of the panaceas if the Nigerian Government wants to achieve "housing for all by the year 2030."

\section{CONCLUSION AND RECOMMENDATION}

As a nation, LCH provision in Nigeria should start with the government at all levels. At the federal level, the National Housing Policy should be reviewed with policies and programmes that are feasible and pro-poor homeownership tailored towards effective housing delivery in line with Buckley and Kalarickal (2005). This would allow the country to attain the United Nation's Sustainable Development Goal of putting an end to extreme poverty by the year 2030 via homeownership. Homeownership is a good example of balancing the wealth gap, and a medium of perfect prosperity distribution. The need for the Nigerian Government to consistently demonstrate a commitment to tackling the challenge of LCH deficiency cannot be over-stressed. Thus, this paper recommends that the Nigerian Government should adopt the Malaysian Government LCH policies and programmes with all sincerity. This recommendation is in line with Stephens (2011) and Scanlon and Elsinga (2014) studies regarding the theory of being system-embedded that emerged from the concept of Kemeny's study. The "system-embedded research" is a concept that marks a development from existing "middle ways," being discovered on the idea that guiding principle is visualised inside wider housing systems and housing systems themselves operate inside wider social and economic structures (Stephens, 2011). Thus, the policy-related comparative housing study can harvest soaring returns in the Nigerian housing sector if implemented as part of the study's practical implications because there are no grave risks as both countries operate a democratic federal system of government.

A mechanism to build a sustainable housing finance system for low-income households should be considered by the Nigeria Mortgage Refinance Company. This is because the present housing programme of the Mortgage Refinance Company is tailored towards the medium and medium-high income earners housing provision. The institutional frameworks that would sustain the Nigeria Mortgage Refinance Company for continuity should be strengthened and enhanced towards housing for all with special consideration given to the low-income group. Also, the Central Bank of Nigeria should review the policy on mortgage lending rates to make it pro-poor homeownership friendly as applicable in Malaysia. Thus, it is all about the transferability of housing policy. This effort should be complemented by respective states via land allocations and financial subsidies to private developers and non-profit organisations that construct LCH projects. This would boost the availability of $\mathrm{LCH}$ in the system.

The government should set policies that would enable the Nigerian Pension Scheme contributors to have access to a percentage of their savings while still in service via the National Pension Commission for making part or full payment for the purchase of a home. This is one of the strategies of the Malaysian Government in LCH provision for the LIEs. This is a scheme that is having an average inflow of about $\$ 200$ million monthly. If the suggested mechanism is fully utilised, the issue of housing loan encumbrances for the LIEs will become a thing of the past in Nigeria. Fraud and diversion of the fund should be checked meticulously by the anti-corruption agencies during this process. In addition to the government leading in LCH provision, the government should control selling price for $\mathrm{LCH}$ and regulations imposed to private developers for the compulsory provision of a percent of LCH for every residential project, with sanctions well defined should there be defaulters. The government agencies in charge of implementation and monitoring should be ethically above board in their dealings. This is pertinent in making LCH for the low-income group a reality in Nigeria. Also, the federal should direct states to coordinate the computerised open registration system of eligible house buyers at the senatorial level and linked with the federal database via the database of the respective state. The eligible Nigerian citizen qualified for LCH should not be a homeowner and government should set-up mechanism that can verify the informal income earners to mitigate leakages during allocation, either by assessment of their business that generates the monthly income or other methodology that will be acceptable and seem as transparent by all.

There should be synergy between the Nigeria Mortgage Refinance Company, Central Bank of Nigeria, Federal Housing Authority, Housing Developers Association, Banking Association of Nigeria and other housing 
market stakeholders to develop a uniform underwriting standard for the huge and untapped LIEs in the private formal and informal sectors to have access to finance for the purchase of homes. The Nigerian Government should lead in this direction and all appropriate agencies should set and pursue policies and programmes that would be pro-poor homeownership. Now is the time for the Nigerian Government to appreciate that housing likewise has a noteworthy in defining ways of life and organising the cities and its surrounding. The Malaysian Government succeeded in the private formal sector via the mandatory Employee Providence Fund contribution. The Nigerian Government should adopt this model for the LIEs in the private formal sector. This article shows that housing policies of countries that have recorded success in homeownership for the poor and disadvantaged could be modified and applied in the context of the countries having challenges. This is part of the practical implications and pioneering the transformation of $\mathrm{LCH}$ provision for liveable sustainable cities across Nigeria. The Nigerian Government role in building and ensuring a sufficient supply of LCH cannot be over-emphasised through the implementation of these practicable policies with clear-cut direction to address the Nigerian LCH demand-supply gap.

\section{ACKNOWLEDGEMENT}

This work was supported by the Universiti Sains Malaysia [1001/PPBGN/816296].

\section{REFERENCES}

Abdul-Aziz, A-R, \& Kassim, P. S. J. (2011). Objectives, success and failure factors of housing public-private partnerships in Malaysia. Habitat International, 35, 150-157.

Abdul-Aziz, A-R., Tah, J. H. M.., Olanrewaju, A. L., \& Ahmed, A. U. (2018). The nexus between government and private developers in Malaysia housing sector. In U. Sengupta, \& A. Shew (Eds.), Country of age: Trends and issues in housing in Asia Cities (1st ed., pp. 110-136). London, United Kingdom: Routledge.

Abdullahi, C. B. (2013). Low-income housing policy: A comparative study of Malaysia and Nigeria. PhD Thesis submitted to University of Malaysia, Kuala Lumpur, Malaysia.

Adeyemo, I. (2018, April 12). Nigeria’s population now 198 million- NPC. Premium Times. Retrieved from https://www.premiumtimesng.com/news/top-news/264781-nigerias-

Aigbokhan, E. B. (2008). Growth, inequality and poverty in Nigeria. Economic Commission for Africa. ACGS/MPAMS Discussion Paper No.3. Held in Addis Ababa, Ethiopia, June 20.

Ajanlekoko, K. S. (2001). Sustainable housing development in Nigeria - The financial and infrastructural implication. Proceedings of the International Conference on Spatial Information for Sustainable Development. Held in Nairobi, Kenya, 2-5 October 2001.

Akintomide, D. (2016). Only 5\% of Nigerian housing stock affordable; building for LIE not profitable, experts react. Nigerian News Direct. Retrieved from http://nigeriannewsdirect.com/only-5-of-nigerian-housingstock-affordable-building-for-low-income-earners-not-profitable-experts-react/

Alao, T. (2017, August 23). FHA introduces 3 new housing products in Nigeria. Nigerian Tribune, p25.

Aliu, R. I., Towry-Coker, L., \& Odumosu, T. (20180. Housing policy debacle in Sub-Saharan Africa: An appraisal of three housing programmes in Lagos Nigeria. African Geographical Review, 37(3), 241-256.

Alves, S. (2017). Polrs apart? A comparative study of housing policies and outcomes in Portugal and Denmark. Housing, Theory and Society, 34(2), 221-248. doi.org/10.1080/14036096.2016.1236036

Amaefule, E. (2017, September 26th). Nigeria's housing deficit too high- Osinbajo. Punch Newspaper. Retrieved from https://punchng.com/nigerias-housing-deficit-too-high-osinbajo/ 
Aribigbola, A. (2008). Housing policy formulation in developing countries: evidence of programme implementation from Akure, Ondo State, Nigeria. Journal of Human Ecology, 23(2), 125-134.

Aribigbola, A., \& Ayeniyo, I. O. (2012). Sites and services as a strategy for achieving adequate housing in Nigeria in the 21st century. International Journal of Humanities and Social Sciences, 2(2), 126- 132.

Awodele, O. A. (2012). Framework for managing risk in financed market project in Nigeria. PhD Thesis submitted to Heriot-Watt University, United Kingdom.

Bahare, F. (2017). Evaluation of national policy toward providing low-cost housing in Malaysia. International Journal of Social Sciences, 6(1), 9-19.

Bengtsson, B. \& Ruonavaara, H. (2011). Comparative process tracing in housing studies. International Journal of Housing Policy, 11(4), 395-414. doi.org/10.1080/14616718.2011.626603

Buckley, M. R., \& Kalarickal, J. (2005). Housing policy in developing countries: Conjuntures and refutations. The World Bank Researcher Observer, 20(2), 233-257.

Bureau of Public Service Reform. (2017, February 10th). Housing shortage in Nigeria surges. Construction Review. Retrieved from https://constructionreviewonline.com/2017/02/housing-shortage-in-nigeriasurges/

Denis, C. A. (2011). A long-term analysis of housing affordability in Malta. International Journal of Housing Markets and Analysis, 4(1), 23-29.

Ebekozien, A. (2019). Root cause analysis of demand-supply gap to low-cost housing in Malaysia. PhD thesis submitted to Universiti Sains Malaysia, Malaysia.

Ebekozien, A., Abdul-Aziz, A-R., \& Jaafar, M. (2017). Comparative analysis of low-cost housing policies in Malaysia and Nigeria. International Transaction Journal of Engineering, Management, \& Applied Sciences \& Technologies, 8(3), 139-152.

Ebekozien, A., Abdul-Aziz, A-R, B., \& Jaafar, M. (2018). Low-cost housing leakages in Malaysia: The unexplored dimension. Pacific Rim Property Research Journal, 24(3), 249-264. doi.10.1080/14445921.2018.1552471

Ebekozien, A., Abdul-Aziz, A-R., \& Jaafar, M. (2019A). Low-cost housing policies and squatters in Nigeria: The Nigerian perspective on possible solutions. International Journal of Construction Management. doi.10.org/10.1080/15623599.2019.1602586

Ebekozien, A., Abdul-Aziz, A-R, B., \& Jaafar, M. (2019B). Housing finance inaccessibility for low-income earners in Malaysia: Factors and solutions. Habitat International, 87, 27-35. doi.10.1016/j.habitatint.2019.03.009

Eleventh Malaysia Plan. (2016). Eleventh Malaysia Plan 2016-2020. Kuala Lumpur, Malaysia: Percetaken Nasional Malaysia Berhad.

Fahey, T., \& Norris, M. (2011). Housing in the welfare state: Rethinking the conceptual foundations of comparative housing policy analysis. International Journal of Housing Policy, 11(4), 439-452. doi.org/10.1080/14616718.2011.626606

Fernandez, E. (2013). Housing finance: Key issues for housebuyers. In O. S. Kuang (Ed.), Housing the nation: Policies, issues, and prospects (1st ed., pp. 137-148). Kuala Lumpur, Malaysia: Cagamas Berhad.

Ibem, E. O. (2012). An assessment of the role of government agencies in public-private partnerships in housing delivery in Nigeria. Journal of Construction in Developing Countries, 15(2), 23- 48. 
Ibem, E. O., Anosike, M. N., \& Azuh, D. E. (2011). Challenges in public housing provision in the post independence era in Nigeria. International Journal of Human Sciences, 8(2), 421-443.

Ibem, E. O., Opoko, A. P., \& Aduwo, E. B. (2013). The challenges of public housing in a democratic Nigeria: a case study of the Presidential Mandate Housing Scheme. Scottish Journal of Arts, Social Sciences and Scientific Studies, 9(1), 23-39.

Ibimilua, A. F., \& Ibitoye, O. A. (2015). Housing policy in Nigeria: an overview. American International Journal of Contemporary Research, 5(2), 53-59.

Ilesanmi, O. A. (2010). Post-occupancy evaluation and residents' satisfaction with public housing in Lagos, Nigeria. Journal of Building Appraisal, 6(2), 153-169.

Kazeem, Y. (2018, June 25). Nigeria has become the poverty capital of the world. Quartz Africa. Retrieved from https://qz.com/africa/1313380/nigerias-has-the-highest-rate-of-extreme-poverty-globally/

Keivani, R., \& Werma, E. (2001a). Modes of housing provision in developing countries. Progress in Planning, 55, 65-118.

Keivani, R., \& Werma, E. (2001b). Refocusing the housing debate in developing countries from a pluralist perspective. Habitat International, 25, 191-208.

Kemeny, J. (2001). Comparative housing and welfare: Theorising the relationship. Journal of Housing and the Built Environment, 16, 53-70.

Kemeny, J., \& Lowe, S. (1998). Schools of comparative housing research: From convergence to divergence. Housing Studies, 13(2), 161-176.

Maslow, A. H. (1943). A theory of human motivation. Psychological Review, 50(4), 370-396.

Ministry of Urban Wellbeing, Housing and Local Government. (2013). The national housing policy. In O. S. Kuang (Ed.), Housing the nation: Policies, issues and prospects (1st ed., pp. 107-116). Kuala Lumpur, Malaysia: Cagamas Holdings.

Mohammed, Y. U., David, M., \& Seow, T. W. (2012). The current practices of the Malaysian formal low- cost housing provision system. Proceedings of the International Conference of Technology Management, Business and Entrepreneurship. Held in Kuala Lumpur, Malaysia, May 29, pp.211- 237.

Mortgage Digest. (2016A). MD/CEO’s welcome address. Mortgage Digest, 1(1), 1.

Mortgage Digest. (2016B). NMRC refinances N7.8billion worth of mortgages. Mortgage Digest, $2(2), 1$.

Mortgage Digest. (2017). CBN policy on mortgage lending rates. Mortgage Digest, 1(4), 7.

Odunsi, W. (2017, August 28). CBN reveals how Nigerians can own a new home, pay within 25 years. Daily Post. Retrieved from www.dailypost.ng/2017/08/28/cbn

Okonkwo, M. M., Agbonome, P. C., \& Chiroma, A. H. (2012). Identifying and housing of the urban poor in Nigeria: Adequacy of the "FEDUP". ESC Journal, 2(2), 1-15.

Okoroafor, P. (2007). Critical issues in the development of viable housing finance industry in Nigeria. Proceedings of the 2nd Emerging Urban African International Conference and Exhibition on Housing Finance in Nigeria. Held in Abuja, 17-19 October.

Olufowobi, S. (2017, October 10). Ambode promises 20,000 houses in three years. The Punch News. Retrieved from www.onlinenigeria.com/site/stories/365478-ambode-promises- 20000-houses-in- threeyears.html 
Onibokun, A. G. (1985). Housing needs and responses: A planner's viewpoints. In A. G. Onibokun (ed.), Housing in Nigeria (1st ed. pp. 34-45). Ibadan, Nigeria: Nigerian Institute for Social and Economic Research.

Oyo-Ita, E. W. (2017). Tackling the housing affordability challenge: Nigeria experience. Proceedingsof the 30th International Union for Housing Finance (IUHF) World Congress on "Global Opportunities in Housing Finance." Held in Washington DC, USA, June 27th.

Parker, M. (2016, October 20). Huge challenges of urban housing. New Straits Times. Retrieved from https://www.nst.com.my/news/2016/10/181744/huge-challenges-urban-housing.

Phang, S-Y. (2018). Policy innovations for affordable housing in Singapore: From colony to global city. Cham, Switzerland: Palgrace Macmillan.

Pigou, A. C. (1932). The economics of welfare. London, United Kingdom: Macmillan.

Piketty, T. (2014). Capital in the twenty-first century. Cambridge, USA: Harvard University.

Pugh, C. (2001). The theory and practice of housing sector development for developing countries, 1950-1999. Housing Studies, 16(4), 399-423. doi.10.1080/02673030120066527

Punch Newspaper. (2016, October 11th). Federal government raise one trillion naira for housing scheme-Osinbajo. Punch Newspaper. Retrieved from https://punchng.com/fg-raise-n1trn-housing-scheme- osinbajo/

Raschke, C. (2016). Best practices: Affordable housing in Nigeria. Bonn, Germany: Inclusive Business Action Network.

Scanlon, K., \& Elsinga, M. (2014). Policy changes affecting housing and mortgage markets: How governments in the UK and the Netherlands responded to the GFC. Journal of Housing and the Built Environment, 29(2), 335-360.

Shuid, S. (2016). The housing provision system in Malaysia. Habitat International, 53(3), 210-223. doi: 10.1016/j.habitatint.2015.11.021

Stephens, M. (2011). Comparative housing research: A 'system-embedded' approach. International Journal of Housing Policy, 11(4), 337-355.

Stone, M. E. (2006). What is housing affordability? The case for the residual approach. Housing Policy Debate, 17(1), 151-184.

Tenth Malaysia Plan. (2011). Eleventh Malaysia Plan 2011-2016. Kuala Lumpur: Percetaken Nasional Malaysia Berhad.

The Guardian. (2017, April 12). Moves to tackle affordable housing shortage in Nigeria. The Guardian Newspaper. Retrieved from https://oxfordbusinessgroup.com/news/moves-tackle-affordable-housingshortage-nigeria

The Star Online. (2018, November 2). Budget 2019: Bank Negara's measures for affordable homes. The Star Online: Retrieved from https://www.thestar.com.my/business/business- news/2018/11/02/bnm-specialmeasures-for-affordable-homes/

United Nations Habitat II. (1996). Report of the United Nations conference on human settlements (Habitat II). Istanbul: United Nations.

UN-HABITAT. (2006). National trends in housing - production practices Volume 4: Nigeria, Nairobi: United Nations Centre for Human Settlements. Abuja: United Nations. 
United Nations Habitat. (2010). The state of African cities 2010- governance, inequality, urban landmarkets, Nairobi: United Nations Human Settlements Programme. Abuja, Nigeria: United Nation.

Wahab, E. (2006). Independent judiciary and sustainable democracy. In challenges of sustainable democracy in Nigeria (1st ed., pp209-234). Ibadan, Nigeria: John Archers.

Wapwera, S. D., Parsa, A., \& Egbu, C. (2011). Financing low income housing in Nigeria. Journal of Financial Management of Property and Construction, 16(3), 283-291.

World Bank Press Release. (2017, March 20). World Bank approves new financing to support affordable housing in Indonesia. Retrieved from www.worldbank.org/en/news/press-release/2017/03/20/world-bankapproves. 